\title{
PENERAPAN MODEL PEMBELAJARAN KOOPERATIF TIPE SNOWBALL THROWING PADA PEMBELAJARAN SEGIEMPAT UNTUK MENINGKATKAN AKTIVITAS DAN PRESTASI BELAJAR SISWA SMPN 1 LINGSAR KELAS VII-1 TAHUN PELAJARAN 2012/2013
}

\author{
Ristu Haiban Hirzi' ${ }^{1}$, Sripatmi², Hapipi ${ }^{2}$ \\ ${ }^{1}$ Alumni Prodi Pendidikan Matematika FKIP Unram \\ ${ }^{2}$ Dosen Prodi Pendidikan Matematika FKIP Unram \\ Email: hapipiunram@gmail.com
}

\begin{abstract}
Abstrak: Penelitian ini bertujuan untuk meningkatkan aktivitas dan hasil belajar siswa SMPN 1 Lingsar kelas VII-1 pada materi segi empat melalui penerapan model pembelajaran Kooperatif tipe Snowball Thowing. Penelitian ini merupakan penelitian tindakan kelas yang dilaksnakaan dalam 2 siklus. Hasil penelitian menunjukkan bahwa penerapan model pembelajaran tersebut dapat memperbaiki aktivitas dan hasil belajar siswa. Hal ini ditunjukkan oleh skor aktivitas siswa tergolong tinggi pada siklus I dan sangat tinggi pada siklus II. Sedangkan skor rata-rata hasil evaluasi belajar siswa mengalami peningkatan pada tiap siklus yaitu pada siklus I rata-rata skor hasil evaluasi belajar 58,2 dengan ketuntasan klasikal 50\% dan pada siklus II skor rata-rata hasil evaluasi belajarnya mencapai 85,74 dengan ketuntasan klasikal 89\%. Capaian tersebut menunjukkan bahwa penerapan Model Pembelajaran Kooperatif tipe Snowball Throwing pada pembelajaran segiempat dapat meningkatkan aktivitas dan prestasi belajar siswa SMP Negeri 1 Lingsar kelas VII-1 tahun pelajaran 2012/2013.
\end{abstract}

Kata kunci: Kooperatif tipe snow ball throwing, aktivitas belajar, hasil belajar.

Abstract: This research aims to improve the activity and student learning outcomes SMPN 1 Lingsar class VII-1 on the rectangular material through the implementation of cooperative learning model type thowing Snowball. This research is a classroom action research conducted in two cycles. The results showed that the application of the learning model can improve the activity and student learning outcomes. This is demonstrated by the student activity score relatively high on the first cycle and very high in the second cycle. While the average score on the evaluation of student learning has increased in each cycle, namely in the first cycle an average score of 58.2 on the evaluation study with classical completeness $50 \%$ and the second cycle the average score on the evaluation study reached 85.74 with classical completeness $89 \%$. These achievements show that the application of cooperative learning model type Snowball Throwing on the rectangular material can increase the activity of learning and student achievement SMP Negeri 1 Lingsar class VII-1 of the school year 2012/2013.

Keywords: snowball throwing cooperative type, learning activity, learning outcomes

\section{Pendahuluan}

Matematika sebagai salah satu mata pelajaran di sekolah dinilai cukup memegang peranan penting dalam membentuk siswa menjadi berkualitas, karena matematika merupakan suatu sarana berpikir untuk mengkaji sesuatu secara logis dan sistematis. Penguasaan ilmu ini sangat dibutuhkan oleh siswa baik dalam pendidikan di sekolah maupun dalam kehidupan sehari-hari, karena begitu banyak aktifitas yang dilakukan dalam kehidupan yang melibatkan matematika. Mengingat pentingnya peranan matematika, maka prestasi belajar khususnya untuk mata pelajaran matematika di sekolah harus diperhatikan.

Namun hingga dewasa ini tidak dapat dipungkiri bahwa matematika masih menjadi salah satu mata pelajaran yang dianggap sulit oleh kebanyakan siswa. Hal tersebut dapat menjadi kesan awal yang kurang baik bagi peserta didik sehingga dalam pembelajaransiswa cenderung kurang antusias dan kurang aktif. Akibatnya prestasi belajar siswa kurang memuaskan. Keadaan serupa juga terjadi pada SMP Negeri 1 Lingsar dimana prestasi belajar siswa juga kurang memuaskan.
Tabel 1. Data hasil ujian tengah semester 1 kelas VII SMP Negeri 1 Lingsar Tahun Pelajaran 2012/2013

\begin{tabular}{|l|c|c|}
\hline Kelas & Rata-rata Nilai & $\begin{array}{c}\text { Ketuntasan Belajar } \\
\text { klasikal }\end{array}$ \\
\hline VII-1 & 54,34 & $25,00 \%$ \\
\hline VII-2 & 56,60 & $30,00 \%$ \\
\hline VII-3 & 57,38 & $26,32 \%$ \\
\hline VII-4 & 62,12 & $34,61 \%$ \\
\hline \multicolumn{2}{|c|}{ (Sumber: daftar nilai guru matematika SMP Negeri 1 } \\
Lingsar).
\end{tabular}

Dari tabel 1 di atas terlihat bahwa setiap kelas belum bisa mencapai persentase ketuntasan belajar klasikal yang ditetapkan sekolah yaitu $85 \%$. Hal ini menunjukkan bahwa masih banyak siswa yang belum tuntas dalam pelajaran matematika.Terlebih lagi kelas VII-1 memiliki ketuntasan klasikal yang paling rendah dari semua kelas VII yang ada di SMP Negeri 1 Lingsar.

Berdasarkan observasi selama PPL di SMPN 1 lingsar yang berlangsung dari tanggal 29 juli - 2 Desember 2012 diketahui bahwa rendahnya prestasi belajar siswa SMPN 1 Lingsar disebabkan oleh berbagai faktor diantaranya adalah rasa tidak percaya 
diri siswa yang tinggi. Siswa cenderung tidak memiliki keberanian untuk menyampaikan pendapat maupun kesulitan yang mereka hadapi selama pembelajaran di depan teman- temannya. Disamping itu pembelajaran yang digunakan guru lebih sering dengan pembelajaran konvensional yang biasa dilakukan dengan penyajian materi secara ceramah dilanjutkan dengan pemberian contoh soal diikuti dengan tugas. Dengan kegiatan seperti ini siswa hanya menerima mentah-mentah apa yang diutarakan oleh guru tanpa ikut berpartisipasi dalam menemukan konsep. Akibatnya, seringkali siswa merasa kesulitan dalam belajar matematika sehingga siswa cenderung tidak berpartisipasi aktif dalam pembelajaran.

Melihat fenomena tersebūt, maka perlu diterapkan pembelajaran yang melibatkan peran siswa secara aktif dalam kegiatan belajar mengajar, guna meningkatkan prestasi belajar matematika siswa. Model pembelajaran yang memungkinkan tumbuhnya partisipasi aktif siswa adalah model pembelajaran kooperatif. Sebgaimana dinyatkan Isjoni [1] bahwa dalam pembelajaran kooperatif, siswa terlibat aktif pada proses pembelajaran sehingga memberikan dampak positif terhadap kualitas interaksi dan komunikasi yang berkualitas, dapat memotivasi siswa untuk meningkatkan prestasi belajarnya. Salah satu tipe kooperatif yang dapat diterapkan sesuai karakteristik masalah di atas adalah kooperatif tipe Snowball Throwing. Melalui model pembelajaran ini siswa dapat mengemukakan pemikirannya, saling bekerja sama jika ada teman dalam kelompoknya yang mengalami kesulitan, dan saling bertukar fikiran melalui penyampaian pendapat maupun pengajuan pertanyaan terhadap kebingungan yang dialaminya. Hal ini dapat meningkatkan motivasi siswa menjadi lebih aktif untuk mengkaji pelajaran matematika sehingga nantinya akan meningkatkan prestasi belajar matematika siswa.

Pembelajaran dengan Snowball Throwing ini dapat menjembatani siswa yang memiliki rasa percaya diri yang rendah untuk bertanya, karena permasalahan yang mereka miliki dapat disampaikan melalui kertas yang dibentuk menjadi bola (Snowball). Pembelajaran ini juga dapat mengakomodasi partisipasi siswa yang cenderung pasif dalam bediskusi. Sehingga dalam pembelajaran, siswa tersebut tidak hanya duduk diam didalam kelas. Oleh karena itu, penelitian ini menjadi penting untuk dilakukan.

\section{Metode Penelitian}

Jenis penelitian ini adalah penelitian tindakan kelas (classroom action reseach). Penelitian tindakan kelas (PTK) adalah suatu penelitian yang dilakukan oleh guru atau seseorang tertentu di dalam kelas dengan tujuan untuk memperbaiki kinerja sebagai guru, sehingga hasil belajar siswa menjadi meningkat [2].

Penelitian ini dilaksanakan di SMP Negeri 1 Lingsar. Subjek dari penelitian ini adalah siswa kelas VII-1 Tahun Pelajaran 2012/2013 yang berjumlah 23 orang. Adapun faktor-faktor yang diteliti dalam penelitian ini adalah: 1) faktor siswa yang terdiri dari peningkatan aktivitas dan prestasi belajar matematika siswa pada materi segiempat melalui penerapan model pembelajaran cooperative tipe snowball throwing; dan 2) faktor guru yaitu aktivitas guru selama pembelajaran melalui penerapan model pembelajaran cooperative tipe snowball throwing.

Prosedur penelitian yang digunakan dalam penelitian ini, yaitu prosedur penelitian tindakan kelas yang dilaksanakan dalam dua siklus. Masing-masing siklus mengikuti tahapan perencanaan tindakan, tahap pelaksanaan tindakan, tahap observasi, tahap evaluasi, serta tahap refleksi. Materi siklus I meliputi pengertian persegi panjang, sifat-sifat persegi panjang, dan menentukan keliling dan luas persegi panjang. Sedangkan materi siklus II meliputi pengertian persegi, sifat-sifat persegi, dan menentukan keliling dan luas persegi. Adapaun indikator keberhasilan yang ditetapkan penelitian ini adalah meningkatnya aktivitas (kategori tinggi) dan meningkatnya prestasi belajar siswa (terjadi ketuntasan klasikal) pada materi segi empat.

\section{Hasil dan Pembahasan}

Penelitian tindakan kelas ini dilaksanakan dengan tujuan meningkatkan aktivitas dan prestasi belajar siswa SMPN 1 Lingsar Kelas VII-1 tahun ajaran 2012/2013 pada materi pokok persegi panjang dan persegi melalui penerapan pembelajaran Cooperative tipe Snowball Throwing. Secara keseluruhan, hasil yang diperoleh dalam penelitian ini dapat dilihat dari tabel 2 berikut.

Tabel 2: Hasil penelitian siklus I dan II

\begin{tabular}{|c|c|c|c|c|c|c|}
\hline \multirow[t]{2}{*}{ Siklus } & \multirow[t]{2}{*}{ Pertemuan } & \multicolumn{3}{|c|}{ Aktivitas siswa } & \multirow{2}{*}{$\begin{array}{c}\text { Rata-rata } \\
\text { nilai }\end{array}$} & \multirow{2}{*}{$\begin{array}{l}\text { Persentase } \\
\text { ketuntasan }\end{array}$} \\
\hline & & Skor & Kategori & $\begin{array}{c}\text { Banyak } \\
\text { siswa }\end{array}$ & & \\
\hline \multirow[t]{3}{*}{1} & $\mathrm{I}$ & 8,6 & Sedang & \multirow[t]{3}{*}{22} & \multirow[t]{3}{*}{57,5} & \multirow[t]{3}{*}{$50 \%$} \\
\hline & I & 10,9 & Tinggi & & & \\
\hline & \multicolumn{3}{|c|}{ Evaluasi siklus I } & & & \\
\hline \multirow[t]{3}{*}{2} & I & 11,4 & Sangat tinggi & \multirow[t]{3}{*}{19} & \multirow[t]{3}{*}{77,6} & \multirow[t]{3}{*}{$89 \%$} \\
\hline & I & 12,8 & Sangat tinggi & & & \\
\hline & \multicolumn{3}{|c|}{ Evaluasi siklus II } & & & \\
\hline
\end{tabular}


Berdasarkan tabel di atas dapat dilihat bahwa aktivitas belajar siswa semakin meningkat tiap siklus. Hal tersebut sejalan dengan peningkatan prestasi belajar siswa berupa nilai rata-rata kelas dan persentase ketuntasan belajar siswa. Sesuai dengan apa yang diungkapkan Sudjana [3] bahwa makin tinggi aktivitas belajar siswa maka semakin tinggi peluang berhasilnya pembelajaran dan penilaian.

Hasil ini juga mengkonfirmasi pernyataan Hamalik [4] yang menegaskan bahwa pengajaran yang efektif adalah pengajaran yang menyediakan kesempatan belajar sendiri atau melakukan aktivitas sendiri. Siswa jika belajar sambil bekerja, mereka akan memperoleh pengetahuan, pemahaman, dan aspekaspek tingkah laku lainnya, serta mengembangkan keterampilan yang bermakna untuk hidup di masyarakat. Suatu proses belajar akan benar-benar efektif manakala dalam prosesnya siswa diajak untuk ikut terlibat secara aktif. Proses belajar sesungguhnya bukanlah kegiatan menghapal semata. Seorang guru tidak dapat dengan serta-merta menuangkan sesuatu ke dalam benak para siswanya, karena mereka sendirilah yang harus menata apa yang mereka dengar dan lihat menjadi satu kesatuan yang bermakna. Tanpa peluang untuk mendiskusikan, mengajukan pertanyaan, memperaktikkan dan barangkali bahkan mengajarkannya kepada siswa yang lain, maka proses belajar yang sesungguhnya tidak akan terjadi.

Namun dari hasil observasi terhadap aktivitas siswa dan kegiatan guru pada siklus I, diperoleh rata-rata skor aktivitas siswa dengan kategori sedang pada pertemuan 1 dan aktif pada pertemuan 2 . Hal ini menunjukkan bahwa pembelajaran belum berlangsung secara optimal. Berdasarkan hasil analisis diketahui bahwa kurang optimalnya hasil evaluasi tersebut disebabkan karena adanya beberapa kekurangan pada siklus 1. Adapun kekurangan yang dimaksud adalah siswa masih terlambat masuk kelas ketika bel pembelajaran berlangsung. Hal ini disebabkan karena karena jam pelajaran matematika pada hari senin berada setelah upacara bendera sehingga siswa cenderung beristirahat untuk ke kantin terlebih dahulu. Aktivitas siswa dalam diskusi kelompok juga masih kurang karena beberapa siswa belum terbiasa berdiskusi dengan pembelajaran ini. Siswa juga masih terlihat kurang aktif dalam berpartisipasi menyampaikan pendapatnya sehingga pemahaman siswa akan konsep kurang baik dan tentunya berpengaruh pada prestasi belajar mereka.

Kurang optimalnya kegiatan pembelajaran pada siklus 1 tidak hanya disebabkan dari faktor siswa, namun juga dari faktor guru yang tidak dapat membuat suasana kelas yang interaktif pada tahap pemberian apersepsi. Hal ini disebabkan karena siswa cenderung diam ketika dimintai pendapat dan lebih suka mengobrol dengan teman sebangkunya. Sehingga pada siklus 1 pembelajaran didominasi oleh beberapa siswa yang biasa mengemukakan pendapat. Ketika memasuki tahap pembagian kelompok, siswa kebanyakan yang tidak setuju mendapatkan teman sekelompoknya dan juga siswa perlu mengatur bangku menjadi meja kelompok, sehingga waktu banyak yang terbuang percuma.

Pengembangan konsep siswa juga kurang maksimal karena siswa banyak yang tidak mempersiapkan alat pembelajaran seperti buku paket, sehingga siswa tidak memiliki pegangan untuk dibaca. Siswa juga cenderung bingung saat membuat pertanyaan sehingga siswa membuat beberapa pertanyaan dari buku paket. Hal ini dapat disebabkan karena siswa tidak mengetahui apa yang ingin mereka tanyakan. Saat kegiatan melempar bola Snowball siswa cenderung bermain dengan saling melempar kertas (bukan Snowball). Hal ini disebabkan karena guru meminta kelompok untuk melempar bola secara bersamaan. Siswa memang terlihat antusias dan senang namun hal tersebut mengakibatkan kelas menjadi ribut. Dari hasil evaluasi dapat dianalisa bahwa siswa masih kesulitan dalam menjawab soal cerita. Hal ini dikarenakan siswa jarang mengerjakan soal dalam bentuk cerita.

Dari beberapa kekurangan tersebut selama siklus I, berpengaruh terhadap prestasi belajar matematika siswa yang telah diadakan. Dari hasil evaluasi yang telah dipaparkan pada tabel diatas, diperoleh rata-rata skor prestasi belajar siswa adalah 57,5 dengan ketuntasan belajar sebesar 50\%, masih dibawah standar yang ditetapkan yaitu $85 \%$. Oleh karena itu perlu diadakan perbaikan untuk pembelajaran pada siklus berikutnya agar diperoleh hasil yang optimal.

Untuk meningkatkan pembelajaran pada siklus selanjutnya, peneliti melakukan perbaikan. Beberapa perbaikan telah dilakukan diantaranya pada tahap pembagian kelompok peneliti membagi kelompok diawal pembelajaran sehingga peneliti dapat menghemat waktu lebih banyak dan diskusi berjalan lebih baik. Saat pemberian apersepsi, siswa diminta secara acak untuk menyampaikan pendapat mereka agar setiap siswa mendapatkan pengalaman belajar sendiri. Peneliti juga menyediakan siswa media pembelajaran seperti fotocopyan materi pelajaran agar siswa tidak beralasan tidak memiliki buku paket.

Pada saat membuat pertanyaan, selain membuat pertanyaan mengenai materi yang tidak dimengerti, siswa juga diminta membuat pertanyaan yang mereka ketahui penyelesaiannya dengan maksud memberikan bantuan pada temannya yang kurang faham. Dalam kelas kooperatif, para siswa diharapkan dapat saling membantu, saling mendiskusikan dan beragumentasi, untuk mengasah pengetahuan yang mereka kuasai saat itu dan menutup kesenjangan dalam pemahaman masing-masing [5]. Pada tahap melempar bola tiap kelompok diminta secara bergiliran untuk melempar bola ke kelompok lain. Dengan cara tersebut, siswa tidak mendapatkan kesempatan untuk bermain dan 
tahap pelemparan juga menjadi semakin singkat. Guru juga memberikan siswa latihan soal berupa soal cerita, agar siswa terbiasa mengerjakan soal cerita. Pada saat evaluasi guru juga memberikan soal cerita yang bentuknya sama dengan latihan-latihan yang pernah dilakukan dalam pembelajaran. Sehingga saat evaluasi siswa memiliki gambaran dalam menjawab soal.

Perbaikan di atas dilakukan dengan baik sehingga aktivitas siswa pada siklus II meningkat menjadi 11,4 pada pertemuan 1 dan 12,8 pada pertemuan 2 dengan kategori masing-masing sangat baik. Persentase ketuntasan belajar klasikal siswa juga meningkat menjadi 89\%. Perbaikan-perbaikan di atas juga berpengaruh terhadap meningkatnya skor rata-rata aktivitas belajar siswa menjadi 77,6. Didukung hasil yang diperoleh pada penelitian ini dari siklus I hingga siklus II, baik dari segi aktivitas belajar maupun hasil evaluasi belajar menunjukkan bahwa model pembelajaran Kooperatif tipe Snowball Throwing mampu memberikan kontribusi terhadap peningkatan aktivitas dan prestasi belajar matematika siswa pada materi persegi panjang dan persegi kelas VII-1 SMP Negeri 1 Lingsar tahun ajaran 2012/2013.

\section{Kesimpulan}

Berdasarkan hasil penelitian dan pembahasan yang telah peneliti uraikan dan sesuai dengan indikator keberhasilan dari penelitian ini, maka dapat disimpulkan bahwa:

1. Penerapan model pembelajaran kooperatif tipe Snowball Throwing dapat meningkatkan aktivitas belajar siswa kelas VII-1 SMPN 1 Lingsar tahun pelajaran 2012/2013 pada pokok bahasan persegi panjang dan persegi. Perolehan skor aktivitas siswa pada siklus I pertemuan I yaitu 8,6 dengan kategori sedang, siklus I pertemuan II yaitu 10,9 dengan kategori aktif, siklus II pertemuan I yaitu 11,4 dengan kategori sangat tinggi dan siklus II pertemuan II yaitu 12,8 dengan kategori sangat tinggi.

2. Penerapan model pembelajaran Cooperative Tipe Snowball Throwing dapat meningkatkan prestasi belajar siswa kelas VII-1 SMPN 1 Lingsar tahun pelajaran 2012/2013 pada pokok bahasan persegi panjang dan persegi. Nilai rata-rata yang diperoleh pada siklus 1 adalah 57,5 dengan ketuntasan belajar klasikal $50 \%$ dan pada siklus 2 nilai rata-rata yang diperoleh adalah 77,6 dengan ketuntasan belajar klasikal adalah $89 \%$.

\section{DAFTAR PUSTAKA}

[1]. Isjoni. 2010. Cooperative Learning. Alfabeta. Bandung.

[2]. Wardani, I.G.A.K., dkk, 2003. Penelitian Tindakan Kelas. Pusat Penerbitan Universitas Terbuka. Jakarta.

[3]. Sudjana.2000. Dasar-dasar Proses Belajar
Mengajar. Sinar Baru Algesindo. Bandung.

[4]. Hamalik. 2011. Proses Belajar Mengajar. Bumi Aksara, Jakarta.

[5]. Slavin, R. E. 2010. Cooperative Learning: Teori, Riset dan Praktik. Nusa Media. Bandung. 